\title{
Geology of the eastern Himalayan syntaxis
}

\author{
Yan Liu†*, Zsolt Bernerł, Hans-J oachim Massonne§ and Xuchang Xiao† \\ $\dagger$ Institute of Geology, Chinese Academy of Geological Sciences, Beijing, 100037, CHINA \\ ‡ Institut für Mineralogi e und Geochemie, Universi tät Karl sruhe, Kai serstraße 12, D-76128 Karl sruhe, GERMANY \\ §Institut für Mineralogie und Kristallchemie, Universität Stuttgart, Azenbergstr. 18, D-70174 Stuttgart, GERMANY \\ * To whom correspondence should be addressed. E-mail: yanliu0315@yahoo.com.cn
}

Beforethemiddleof thenineties, theeastern Himalayan syntaxis wasone of theleast-known segmentsof theHimalayas. According to studies several years ago, the eastern Himalayan syntaxis consists of three tectonic units: Gangdise, Yarlung Zangbo, and Himalayan units (Liu and Zhong 1997, Burg et al. 1998). The Gangdise unit consisting of granitoids, migmatites and amphibolite-facies rocks, commonly covered by Palaeozoic and Mesozoic sediments, is separated from the Himalayan unit by the Yarlung Zangbo unit, a mylonitic zone with lenses of metabasitesand serpentinites. Thebasic-ultrabasiclenses of the Yarlung Zangbo unit suggest that the boundary between the Gangdiseand theHimalayan unitsisan eastern extension of the Indus - Yarlung Zangbo suture, which was folded around the eastern Himalayan syntaxis. Recent detailed field mapping has revealed that the Himalayan unit is made up of North Col greenschist to amphibolite facies complex, Greater Himalayan Crystallines, upper Lesser Himalayan Crystallines and lower Lesser Himalayan Crystallinesfrom north to south (Figure1). The dominant mineral assemblage of the North Col complex is plagioclase+quartz+biotite+chlorite+epidote \pm muscovite, butat the bottom of the complex staurolite+kyanite+Kfeldspar+muscovite+quartz+epidote \pm garnet occur. The latter assemblage is different to that at the bottom of the North Col formation of thecentral Himalayas. Aductilenormal fault referred as STD1 here separates the North Col complex from the Greater Himalayan crystallines below. Strongly deformed granites occur between the STD1 and the top of the Greater Himalayan Crystallines. The Greater Himalayan Crystallinesaremarked here by the assemblages garnet+prismatic sillimanite+Kfeldspar+antiperthite or plagioclase. Spinel +al bite+biotite or spinel+cordieritetorthopyroxene form retrograde coronas around sillimaniteand garnet. Theprismatic sillimanitehad been argued to replace early kyanite at elevated temperature, indicating that the Greater Himalayan Crystallines experienced high-pressuremetamorphism (Liu and Zhong1997). TheGreater Himalayan Crystallines were thrust over the upper Lesser Himalayan Crystallines consisting generally of amphibolitic gneisses, sillimanite gneisses, granitic gneisses and marbleby a ductile thrust system which is referred to as the MCT1. Further south, another ductile thrust system, named as the MCT2, separates the upper Lesser Himalayan Crystallinesfrom the lower Lesser Himalayan Crystall lines consisting generally of quartzite, calcschist, limestone, metapsammite and muscovite phyllite (Figure1).

A distinctivefeature of the Greater Himalayan Crystallines is theoccurrence of numerous dykes of variouscompositionsand differentagesalongthefoliation of granulitefaciesgneisses. Three rocktypes can bedistinguished. Onetypeis related to carbonate dykes with fine-grained dark 'chilled' margins from several millimeters to centimeters in thickness and extensive metasomatic and/or contact alteration halos. Large dolomitic dykescommonly contain irregular-shaped xenoliths of granulitic gneiss, which seem to have been separated from source rocks nearby. Spatial relationships of carbonate-rich dykes were observed in the field. These field characteristics resemble those of typically igneous dykes and of mantle-derived carbonatites documented in numerous publications (e.g., LeBas 1981, Tuttle and Gittins 1966). These are also considered as clear indication for an igneousorigin of such carbonatedykes. A second rocktype is characterized by MgO-rich ultramafic rocks, which occur as small dyke-like bodies in the granulitic terrain or as ball-shaped inclusions in diorite dykes. The third group of rocks is related to biotite-bearing diorites.

Geochemically, thecarbonate-rich dykes differ significantly from mantle-derived carbonatites. The dykes are poor in REEs, $\mathrm{Ba}, \mathrm{Sr}, \mathrm{U}, \mathrm{Th}, \mathrm{Nb}, \mathrm{F}$ and $\mathrm{P}$ and their ${ }^{87} \mathrm{Sr} /{ }^{86} \mathrm{Sr},{ }^{143} \mathrm{Nd} /{ }^{144} \mathrm{Nd}, \delta^{18} \mathrm{O}$ (relative to $\mathrm{V}-\mathrm{SMOW}$ ) and $\delta^{13} \mathrm{C}$ (relative to $\mathrm{V}$-PDB) values range from 0.709 to $0.712,0.5117$ to $0.5121,+8 \%$ oto $+24.4 \%$ o, and +0.80 $\%$ oto $+3.55 \%$, respectively. These values are similar to those of many sedimentary carbonates. We suggest that the carbonate dykes wereformed by remobilized melts that originated as partial melts from sedimentary carbonates at crustal levels. Structural analyses haveshown that the hot Greater Himalayan Crystallines were extruded from beneath southern Tibet via ductilechannel flow to overlie the limestone/marble-bearing Lesser Himalayan Crystallines. Remobilization of limestones below the Greater Himalayan Crystallines was probably triggered bystacking of the hot Greater Himalayan Crystallinesincluding interaction of fluids enriched in $\mathrm{H}_{2} \mathrm{O}$ and poor in $\mathrm{CO}_{2}$ probably from the lower crust or even the Earth's mantle. In turn, remobilized carbonatemelts could contribute to the exhumation of the Greater Himalayan Crystallines. According to K-Ar and Ar-Ar data obtained on amphiboleand mica from thecarbonatedykes, thisevent started during the late Neogene.

\section{References}

Burg JP, P Nievergelt, F Oberli, D Seward, P Davy, , JC Maurin, Z Diao and M Meier. 1998. TheNamche-Barwa syntaxis: evidencefor exhumation related to compressional crustal folding. J Asian Earth Sciences 16: 239252

Liu Y and D Zhong. 1997. Petrology of high-pressure granulite from the eastern Himalayan syntaxis. J Met Geol 15: 451-466

LeBas M J. 1981. Carbonatite magmas. Min Mag 44: 133-140

Tuttle O F and J Gittins. 1966. Carbonatites, New York, Wiley, 591 p 


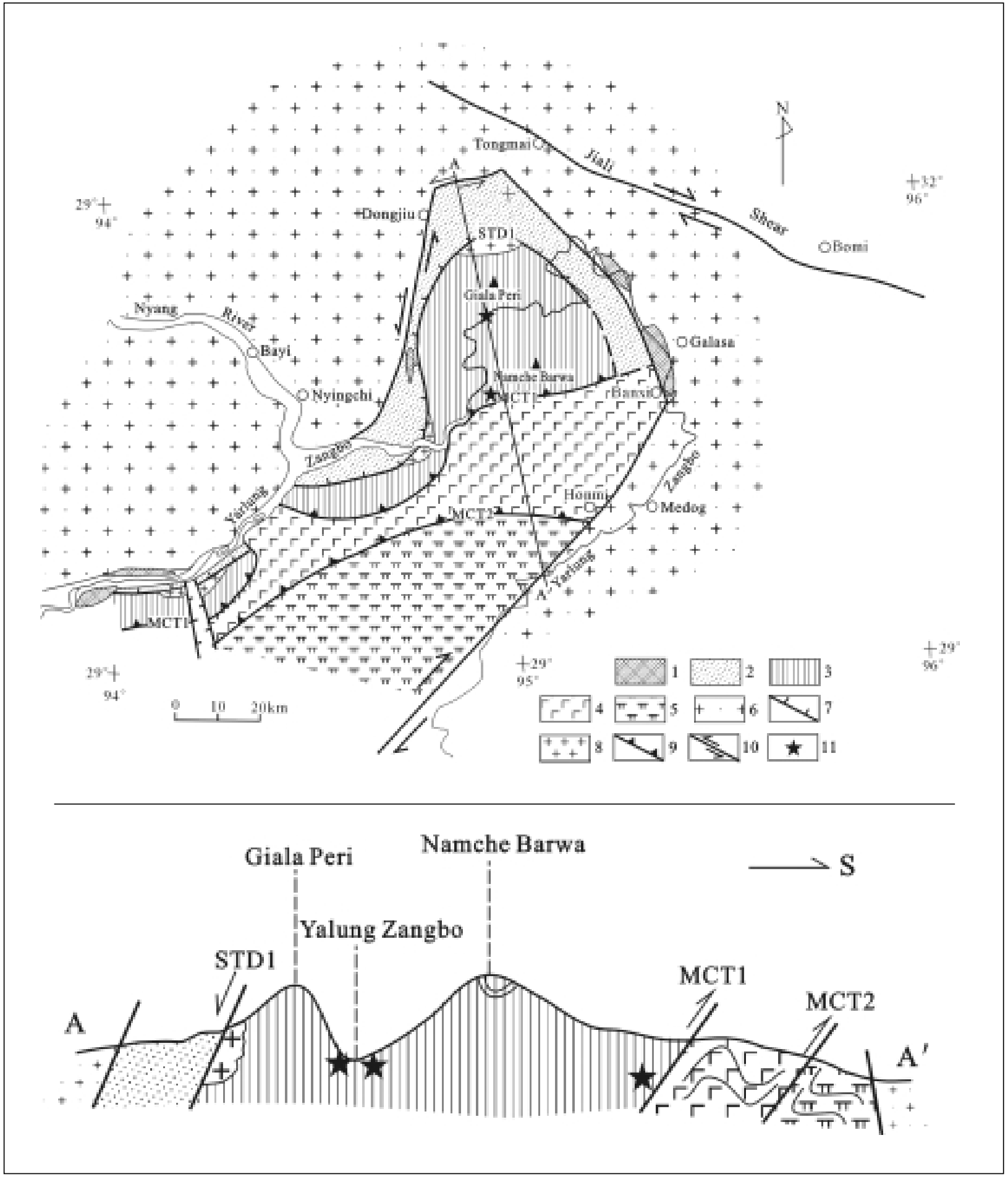

FIGURE 1. Top: Geological sketch map of the eastern Himalayan syntaxis (Liu and Zhong 1997, Burg et al. 1998 and our own observations). Bottom: Geological section. 1, Yarlung Zangbo unit. 2, North Col greenschist to amphibolite facies complex. 3, Greater Himalayan Crystallines. 4, Upper Lesser Himalayan Crystallines. 5, Lower Lesser Himalayan Crystallines. 6, Gangdise unit. 7, Normal fault. 8, Strongly deformed granites. 9, Thrusts. 10, Strike-slip fault. 11, Dyke swarm. 